\title{
ВЛИЯНИЕ СТОМАТОЛОГИЧЕСКИХ ОРТОПЕДИЧЕСКИХ КОНСТРУКЦИЙ НА БИОХИМИЧЕСКИЕ ПОКАЗАТЕЛИ РОТОВОЙ ЖИДКОСТИ
}

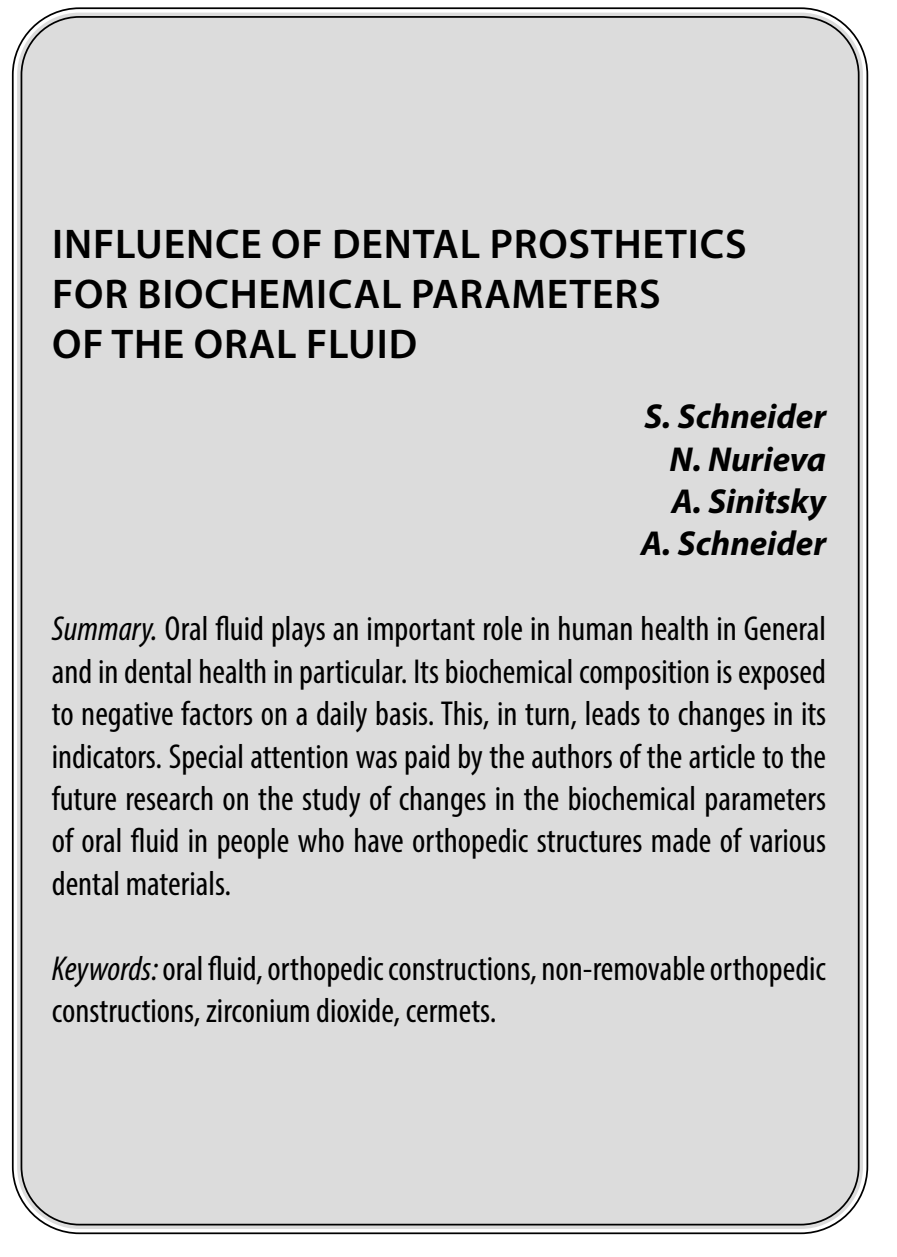

\section{Актуа^ьность}

$\mathbf{P}$ отовая жидкость, или смешанная слюна - это суммарный секрет больших и малых слюнных желез, слущенный эпителий, детрит полости рта, десневая жидкость, зубной ликвор, микрофлора и продукты ее жизнедеятельности, лейкоциты и продукты их распада, остатки пищи, зубной пасты, ополаскивающих жидкостей, бронхиальные и назальные секреты. [3]

Ротовая жидкость, являясь поставщиком различных соединений, обеспечивает поддержание гомеостаза в ротовой полости. Её ионный состав способен изменяться под воздействием как эндогенных, так и экзогенных факторов. Одним из основных показателей ротовой жидкости является $\mathrm{pH}$. В норме $\mathrm{pH}$ составляет 6,4 7,8 Ед. [14] Сдвиг рН может быть обусловлен алиментарными факторами, профессиональными и экологиче-
Шнайдер Семен Давыдович

Соискатель, Дорожная клиническая больница на ст. Челябинск ОАО «РЖД»

shnaider.semen@gmail.com

Нуриева Наталья Сергеевна

Д.м.н., дочент, ФГБОУ ВО «Южно-Уральский государственный медицинский университет» Министерства здравоохранения России (г. Челябинск)

Синицкий Антон Иванович

Д.м.н., дочент, ФГБОУВО «Южно-Уральский государственный медицинский университет» Министерства здравоохранения России (2. Челябинск)

Шнайдер Андрей Давыдович

Соискатель, врач стоматолог-ортодонт, клиника стоматологии ООО «Ортобьюти»

Аннотация. Ротовая жидкость играет важную роль в здоровье человека в целом и в стоматологическом в частности. Ее биохимический состав ежедневно подвергается воздействию негативных факторов. Это, в свою очередь, ведет к изменению ее показателей. Особое внимание было уделено авторами статьи будущему исследованию по изучению исследований изменений биохимических показателей ротовой жидкости у людей, имеющих ортопедические конструкции из различных стоматологических материалов.

Ключевые слова: ротовая жидкость, ортопедические конструкции, несъемные ортопедические конструкции, диоксид циркония, металлокерамика.

скими вредностями, использованием средств гигиены и лекарственных препаратов, протезами, пломбами, микробной обсемененностью полости рта. [12] Изменения в зубочелюстной системе оказывают существенное влияние на состав ротовой жидкости. В связи с этим ее биохимические исследования позволяют выяснить многие особенности патогенеза заболеваний полости рта на молекулярном уровне и обосновать возможности их метаболической коррекции. [11]

Проведя опрос 117 пациентов с несьемными конструкциями установленными в течении 6 месяцев, мы выявляли жалобы на сухость полости рта, воспаление десны вокруг металлокерамических конструкций, изменённый привкус, изменения вкуса, увеличение слюноотделия, покалывание кончика языка. Собрав жалобы, мы решили изучить изменения уникальных свойств биохимических показателей ротовой жидкости. 

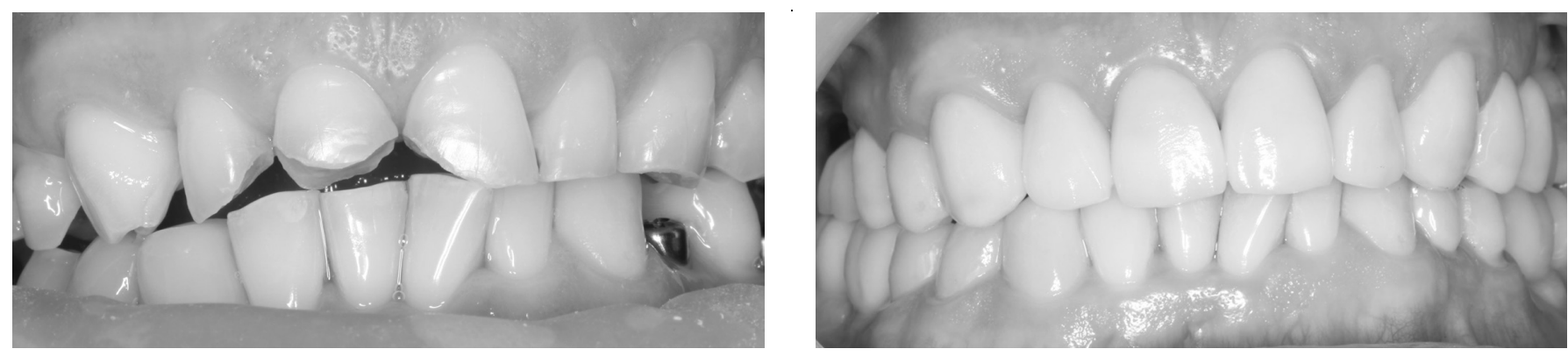

Рис. 1

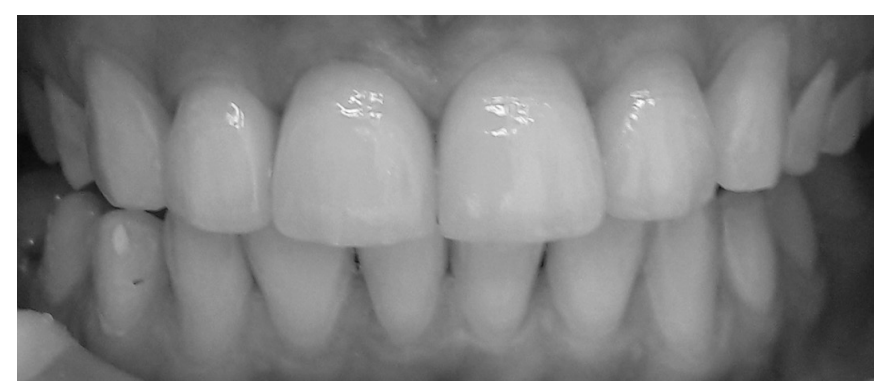

Рис. 2

\section{Цель исслеАования}

Оценить влияние ортопедических конструкций из различных материалов на биохимические показатели ротовой жидкости. При выявлении изменений предложить способ коррекции.

\section{Материалы и метолы}

Планируется провести исследование биологического материала 168 пациентов. Считаем целесообразным разделить их на 3 группы. Первая группа будет представлена относительно здоровыми лицами с сохранными зубными рядами, проходившими наблюдение в рамках диспансеризации взрослого населения. Основные опытные группы, вторая и третья, больные с частичной вторичной адентией разной степени. Пациенты с изготовлением от 2 до 5-ти ортопедических единиц составляют вторую группу. С 6 и более ортопедических единиц объединены в третью группу.

В свою очередь, пациенты второй и третьей групп будут подразделены на несколько подгрупп. Это необходимо для выявления распространенности того или иного материалы ортопедических конструкций. В первую подгруппу будут включены пациенты с конструкциями из металлокерамики. Вторую подгруппу составят пациенты, имеющие конструкции из диоксида циркония. И в третью, последнюю подгруппу войдут пациенты с конструкциями из металлокерамики и диоксида циркония.

При проведении исследования будут соблюдены все этические принципы, изложенные в последней редакции Хельсинской декларации, принятой на 64-й Генеральной ассамблее Всемирной Медицинской Ассоциации (Форталеза, Бразилия, 2013) и Федеральном законе Российской Федерации № 323-Ф3 от 21 ноября 2011 г. «Об основах охраны здоровья граждан в Российской Федерации».

Пациентам будет разъяснена суть исследования, объем их участия, права, обязанности и возможные риски. В исследование будут включены только те лица, которые выразят свое согласие путем подписи добровольного согласия.

Территориально взятие материала будет проходить на базе Стоматологической поликлиники негосударственного учреждения здравоохранения «Дорожная клиническая больница на станции Челябинск открытого акционерного общества «Российские железные дороги».

При первичном осмотре каждому пациенту будет составлен персональный план. На этом этапе врачом-стоматологом-ортопедом будут решены следующие задачи: первичное обследование больного; предварительное планирование зубопротезной рабо- 
ты с целью выявления ортопедических и эстетических факторов, включая диагностическое моделирование в артикуляторе, определяя возможные риски осложнений, тип прикуса и возможности коррекции при необходимости; планирование окклюзионной схемы для оптимального распределения жевательной нагрузки; выбор типа и объема протезирования; материала для фиксации.

В этот период врачом-стоматологом-ортопедом будет оценено: эстетические пожелания и ожидания пациента; высота линии улыбки, длина верхней губы, горизонтальная визуализация зубов, степень обнажения зубов при улыбке и в покое, поддержка тканей лица; твердые ткани зубов, наличие кариеса, некариозные поражения (эрозии клиновидные дефекты, патологическая стираемость) и разрушенность опорных зубов по ИРОП3; форма зубных рядов; воспалительные очаги вокруг периапекальных тканей опорных зубов; межальвеолярную высота, оценка соотношения челюстей; наличие окклюзионных и мышечных парафункций, состояние функции ВНЧС; проведение фотосъемки клинического случая до лечения; изготовление временных реставраций (рис. 1).

В ходе обследования проанализируется состояние гигиены полости рта, общее состояние здоровья, факторы риска, методы и сроки их нивелирования, стоматологический анамнез, результаты осмотра лица, полости рта и данные рентгенографии, медицинские показания и противопоказания к выбору материала для изготовления несъемных ортопедических конструкций, кратность наблюдения после фиксации окончательной работы и сроки контроля. Будет обращено внимание и на наличие воспалительно-деструктивных и иных процессов в полости рта и челюстно-лицевой области. Учтены наличие у пациента вредных привычек. В частности, привычки курения.
Результаты обследования всеми привлеченными специалистами будут вписаны в медицинскую карту пациента с разработанным планом лечения.

На всем протяжении работы с пациентом будет осуществляться сбор ротовой жидкости. Этот процесс так же будет разделен на две части в зависимости от принадлежности пациента к той или иной группе в рамках данного исследования. У пациентов контрольной группы ротовая жидкость будет забрана однократно в ходе осмотра. У больных основной группы забор ротовой жидкости будет производиться в несколько этапов: 1-й этап: в ходе первичного осмотра, перед составлением ортопедического плана лечения; 2-й этап: спустя 14 дней после установки временных ортопедических конструкций; 3-й этап: спустя 7 или 14 дней после фиксации несъёмных ортопедических конструкций; 4-й этап: спустя 30 дней после фиксации несъемных ортопедических конструкций; 5-й этап: спустя 4 месяца после фиксации несъемных ортопедических конструкций.

Собираться ротовая жидкость будет путем сплевывания в пробирку без применения дополнительных методов стимулирования саливации.

\section{Ожилаемые результаты исслеАования}

Выявление степени влияния патологии несъемных ортопедических металлокерамических и из диоксида циркония конструкций на биохимический состав ротовой жидкости. Разработка рекомендаций по ортопедическому ведению пациентов при протезировании несъемными ортопедическими конструкциями (рис. 2).

По результатам проведенного исследования планируются такие формы внедрения как информационные письма, методические рекомендации, публикации в рецензируемых и цитируемых научных изданиях.

\section{ЛИТЕРАТУРА}

1. Анисимова С. В. Стоматологические материалы на основе диоксида циркония / С. В. Анисимова // Dentalforum. — 2008. — № 4 (28). — C. 39-41.

2. Асташина Н. Б. Перспективы использования нономатериалов и высоких технологий в ортопедической стоматологии. Часть 1. / Н. Б. Асташина, В. Н. Анциферов, Г. И. Рогожников [и др.]// Стоматология.— 2014.— № 1.—C. 37-39.

3. Брещенко Е. Е. Биохимия полости рта, ротовой и десневой жидкостей: учебно-методическое пособие для самостоятельной работы студентов стоматологического факультета / Е. Е. Брещенко, И. М. Быков; ФГБОУ ВО КубГМУ.— Краснодар, 2018. - 63 с.

4. Будный А. А. Современные технологии в ортопедической стоматологии / А. А. Будный, И. Д. Плодистая // Bulletin of medical internet cjnferences. - 2018. Vol. 8, is. 7.- P. 288.

5. Массирони Д. Точность и эстетика / Д. Массирони, Р. Пасчетта, Д. Ромео. — Москва: Азбука, 2008. — 381 с.

6. Паршин Ю.В.Особенности ортопедического лечения металлокерамическими и цельнокерамическими зубными протезами (обзор литературы) / Ю. В. Паршин, 0. Н. Сапронова, А. Ю. Медведев // Институт стоматологии. — 2013. — № 1. — С. 87-89.

7. Саламов М.Я. Применение супраструктур дентальных имплантатов, изготовленных из современных керамических материалов, в различных отделах зубного ряда / М. Я. Саламов, А. И. Оганян, Н. А. Цаликова, М. Г. Гришкина // Dentalforum. — 2016. — № 4 (63). — С. 68-69.

8. Фрадеани М. Эстетическая реабилитация несъемными ортопедическим конструкциями / М. Фрадеани.— Москва: Азбука, 2010.— Т. 2.— 465 с. 
9. Хабилов Н.Л. Диоксид циркония - один из современных матотологияеских материалов / Н. Л. Хабилов, М. У. Дадабаева, Т. О. Мун, Б. Н. Хабилов // Stomatologiya. - 2017. - № 2.- С. 107-110.

10. Эльканов А. А. Изучение основных механических свойств конструкционных керамических материалов, используемых для изготовления мостовидных протезов малой протяженности / А. А. Эльканов, Е. А. Брагин, А. Е. Брагин // Современные проблемы науки и образования.— 2017.— № 2.— C. 33-39.

11. Barzilay I. Керамика на основе диоксида циркония и силиката лития. Новый класс керамики / I. Barzilay, E. Behrooz, J. Lopez // Зубной техник. - 2018. № 1.- C. 32-44.

12. Fedorova M. Protein carbonylation as a major hallmark of oxidative damage: update of analytical strategies / M. Fedorova, R. C. Bollineni, R. Hoffmann // Mass spectrometry reviews. - 2014. - Vol. 33, № 2. - P. 79-97.

13. Halliwell B. Radicals in Biology and Medicine / B. Halliwell, J. M. Gutteridge, C. Free.— Oxford: University Press, 2015.— 905 p.

14. Ritter R. G. Применение дисиликата лития при изготовлении люминиров / R. G. Ritter // Зубной техник. — 2011. — № 3. — C. 8-11.

15. Salvi G. E. Prevalence and mechanisms of peri-implant diseases / G. E. Salvi, R. Cosgarea, A. Sculean // Journal of dental research.— 2017.— Vol. 96, № 1.— P. $31-37$.

(c) Шнайдер Семен Давыдович ( shnaider.semen@gmail.com ), Нуриева Наталья Сергеевна,

Синицкий Антон Иванович, Шнайдер Андрей Давыдович.

Журнал «Современная наука: актуальные проблемы теории и практики»

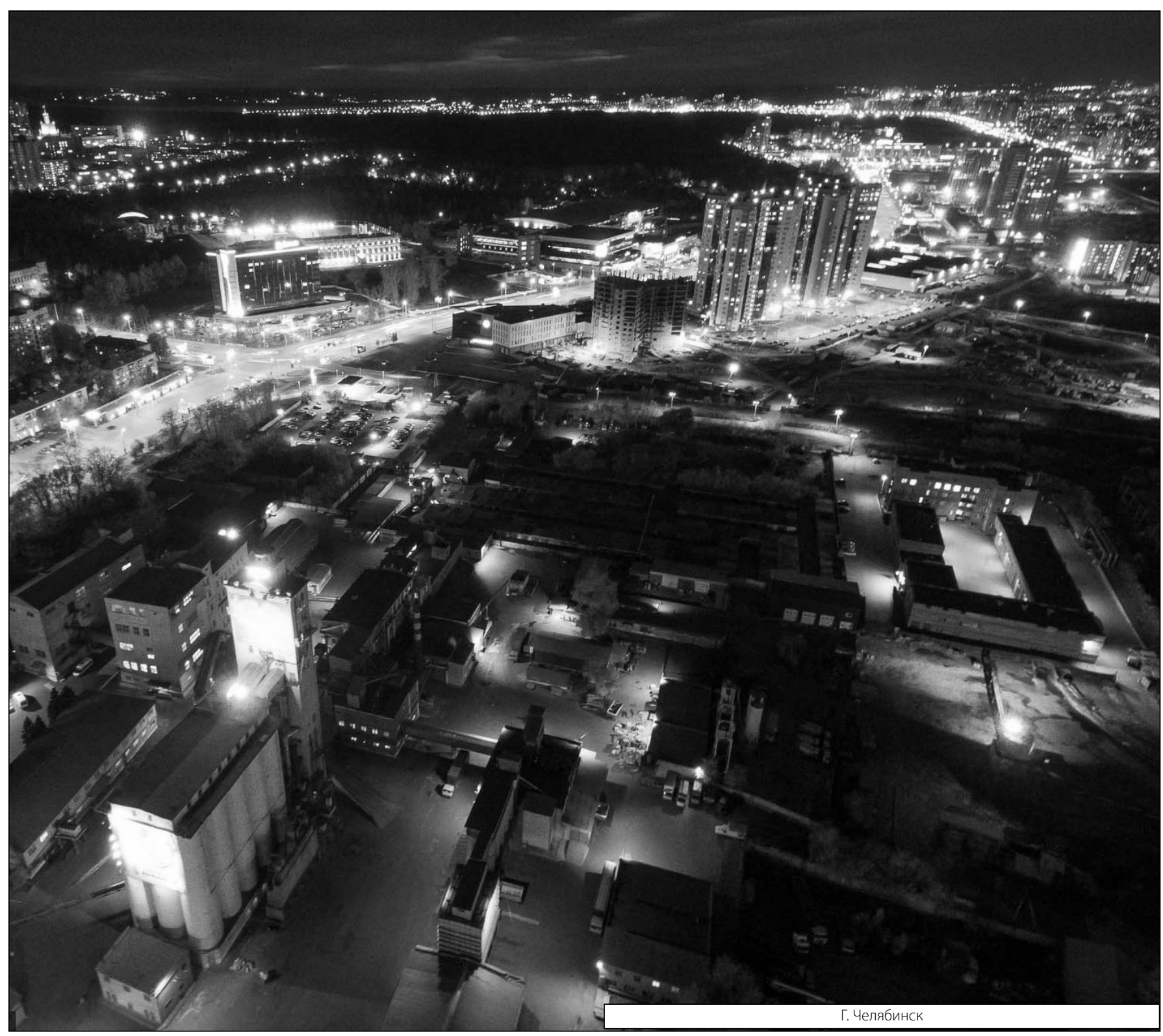

